\section{Energy-Dispersive X-Ray Spectrometry Analysis and Radiopacity of Five Different Root Canal Sealers}

Gözde Kandemir Demirci (D) 1, Mehmet Emin Kaval (D) 1, Seniha Miçooğulları KurtĐ1, Burcu Serefoglu(1), Pelin Güneri(D2, Michael Hülsmann (D) ${ }^{3}$, Mehmet Kemal Caliskan ${ }^{1}$ (D) .

\begin{abstract}
Root canal sealers should have optimum adhesion to the root dentin, low cytotoxicity, sufficient radiopacity and high dimensional stability, which depend mainly on their chemical composition. The aims of this study were to evaluate the chemical composition of Syntex (Cerkamed, Stalowa Wola, Poland), Adseal (Meta Biomed, Cheongju-si, Korea), Sealapex (SybronEndo, Scafati, Italy), MTA Fillapex (Angelus, Londrina, Brazil) and GuttaFlow Bioseal (Coltene/Whaledent, Altstätten, Switzerland) and to determine their radiopacity comparatively. Stainless steel molds with an inner diameter of 5 $\mathrm{mm}$ and a depth of $2 \mathrm{~mm}$ were constructed. Tested root-canal sealers were mixed and poured into the molds. Following setting, digital periapical radiographs of the specimens $(n=12)$ were taken under standard exposure conditions and the mean gray-values of specimens were measured using a computer graphics program. Then the specimens were examined by scanning electron microscopy, and Energy-dispersive X-ray analysis was performed. The data were analyzed using One-way ANOVA followed by Holm-Sidak multicomparison test $(p=0.05)$. Sealapex showed higher calcium peak than MTA Fillapex, GuttaFlow Bioseal, Adseal and Syntex sealers. MTA Fillapex contained a highest amount of tungstate. Sealapex presented the highest radiopacity value among the tested materials $(p<0.05)$, whereas MTA Fillapex was the least radiopaque material $(p<0.05)$. Each root canal sealer contains different compositions of radiopacifiers including bismuth oxide, calcium tungstate and zirconium oxide. The tested root canal sealers had radiopacity values above the ISO-specified limit. Sealapex was the most radiopaque root canal sealer followed by GuttaFlow Bioseal, Syntex, Adseal and MTA Fillapex.
\end{abstract}

\begin{abstract}
1 Department of Endodontology, Faculty of Dentistry, Ege University, Izmir, Turkey

2 Department of Oral and Maxillofacial Radiology, Faculty of Dentistry, Ege University, Izmir, Turkey

3 Department of Operative Dentistry, Periodontology and Cariology, Faculty of Dentistry, University of Göttingen, Göttingen, Germany
\end{abstract}

Correspondence: Dr. Gözde Kandemir Demirci Department of Endodontology, Faculty of Dentistry, Ege University, 35100, Izmir, Turkey. Phone: +902323114608 Fax: +90232388 0325 E-mail: dt.gozdekandemir@hotmail.com

\title{
Introduction
}

Sealing of root canal irregularities and accessory canals during endodontic treatment plays a crucial role for the prevention of microleakage in the root canal system (1). Root canal sealers are intended to fill and seal the gaps between gutta-percha and root canal walls, and thereby enhance the obturation quality (2). In addition to these primary features, a root canal sealer should have optimum adhesion to the root dentin, low cytotoxicity and solubility, high dimensional stability, flowability, long setting time and antimicrobial activity (3), which are completely related to the chemical composition of the material. Besides these optimum properties, the root canal sealer should have an adequate radiopacity to allow discrimination from the anatomical structures and other dental or endodontic materials (4). Additionally, accessory lateral canals, resorptive areas within the canal, root fractures, the apical foramen area can be traced with adequately radiopaque root canal sealers (5).

Sealapex (SybronEndo, Scafati, Italy) was one of the first calcium hydroxide-based root canal sealer with good biological properties $(6,7)$. Its formulation contains zinc oxide, calcium oxide, silicone particles, tricalcium phosphate, zinc stearate, titanium dioxide, bismuth trioxide, isobutyl salicylate, methyl salicylate and pigment (8).

Mineral trioxide aggregate (MTA) has been widely used for various endodontic indications including repair and sealing of perforations, capping of exposed pulp tissue and as a barrier for teeth with open apices $(9,10)$. MTA Fillapex (Angelus, Londrina, PR, Brazil) is a relatively novel MTA-based rootcanal filling material which contains MTA, salicylate, natural and diluting resins, bismuth trioxide, nano particulated silica, and pigments (11).

GuttaFlow Bioseal sealer (Coltene/Whaledent, Altstätten, Switzerland) has been manufactured to promote tissue repair associated with root canal obturation. It has a similar formulation as the GuttaFlow sealer which contains gutta-percha powder, nano-silver particles, polydimethylsiloxane, bioactive glass 
ceramic, zirconium dioxide, platinum catalyst and coloring $(12,13)$. However, GuttaFlow Bioseal sealer includes calcium silicate particles as additional bioactive substances that induce biological repair upon contact with the tissues and stimulate periapical tissue healing (12).

Adseal (Meta Biomed, Cheongju-si, Korea) is a resin-based root canal sealer that contains epoxy oligomer resin, bismuth subcarbonate, ethylene glycol salicylate, zirconium oxide, calcium phosphate, triethanolamine, poly aminobenzoate and calcium oxide (14). Similarly, Syntex (Cerkamed, Stalowa Wola, Poland) is also a resin based two component root canal sealer and comes in a syringe dispensing two pastes in the ratio 1:1 and contains epoxy resin, amino resin, inorganic filler, calcium tungstate, zirconium oxide and excipients.

Knowledge of the chemical composition of root canal fillings whose elements are scattered on the surface of their structures not only can facilitate understanding of their properties and their interaction with the tissues they come into contact with (15), but also helps to evaluate their impact on the radiopacity of the materials. To the authors' knowledge, the relationship between the chemical structures and radiopacity properties of Adseal, GuttaFlow Bioseal, MTA Fillapex, Sealapex and Syntex has not been evaluated previously in the literature. In addition, there is no report about the Energy-dispersive X-ray Spectrometry (EDX) analysis of Adseal and Syntex.

The purpose of this study was to evaluate the chemical composition and particle shape and size of different root canal sealers (Syntex, Adseal, GuttaFlow Bioseal, MTA Fillapex, Sealapex) using scanning electron microscopy (SEM; Thermoscientific Apreo S, Waltham, MA, USA) and EDX (EDAX Team Software; EDAX, Mahwah, NJ, U.S.A.) and their effects on the radiopacity of the test materials.

\section{Materials and methods}

Five different root canal sealers were evaluated: Adseal, GuttaFlow Bioseal, MTA Fillapex, Sealapex and Syntex. Prior to the testing process, a power analysis for radiographic analysis was performed according to a previous study (16). The analyses indicated that minimally seven samples are required; therefore, considering the power analysis, 12 specimens were prepared for radiopacity, SEM and EDX analysis of each group in the present study.

\section{Radiopacity Analysis}

Twelve stainless steel molds with an inner diameter of $5 \mathrm{~mm}$ and a depth of $2 \mathrm{~mm}$ were constructed. Root-canal sealers were mixed according to the manufacturers' instructions and were poured into the molds with disposable syringes in order to obtain 12 samples from each root canal sealer. To eliminate air bubbles inside the material, a dental vibrator (Duradent, Izmir, Turkey) was utilized during the procedure. The filled molds were enveloped with glass plates on the top and bottom to allow removal of excessive root canal sealer. The filled molds were kept in an incubator at $37^{\circ} \mathrm{C}$ until complete setting of the root canal sealers.

A five step 99\% purity aluminum (Al) step wedge (SW) with $2 \mathrm{~mm}$ difference between the steps was used as an internal radiographic standard in order to calculate the radiopacity of each root canal sealer and to compare the radiopacity of the samples. During radiographic procedures, an acrylic positioning device provided a sufficient and standardized focus-object distance $(30 \mathrm{~cm})$ and the x-ray tube was fixed in the same position with the phosphor plate, with a $90^{\circ}$ angle of the central beam. A dentin disc, one root canal sealer specimen from each test group comprising 5 samples aligned in a random sequence and the AI SW were located in the center of a phosphor plate which had not been used before (Digora; Orion Corporation Soredex, Helsinki, Finland). All digital radiographs were obtained under standard exposure conditions ( $60 \mathrm{kVp}, 7 \mathrm{Ma}, 0.32$ seconds, $30 \mathrm{~cm}$ target to film distance) using a dental x-ray machine (Gendex GX, Lake Zurich, IL, USA). The method was identical for all root canal sealer specimens, and a total of 12 digital radiographs were acquired and saved in TIFF format (Figure 1). Exposed phosphor plates were scanned instantly after exposure by using the Digora plate scanner according to the manufacturer's instructions. A region of interest (ROI) with 50x50 pixels was selected on every specimen and on every step of the AI SW on the digital images. Utmost care was afforded to select regions without air bubbles inside the sealer material. Mean gray values (MGVs) of the ROls of every test sample, each step of AI SW and dentin were evaluated using the histogram function of a computer graphics program (Adobe Photoshop 8.0, Adobe System, San Jose, CA, USA) (Figure 1). The MGVs of all samples were measured three times and the mean MGV of each material was calculated. Density measurements of the materials were performed by a single operator who was blinded to the tested root canal sealers. For each digital image, a regression curve equation was defined by using the MGVs of each AI SW step and the radiopacity of the root canal sealer specimen was established in millimeters of equivalent $\mathrm{Al}(\mathrm{mm} \mathrm{Al})$. In this procedure, the radiopacity curve of that film was determined 
on every digital image by using the average grayness values of the steps of AI SW with known thicknesses. Then, a formula was calculated for each film in order to express the MGV measurements in terms of $\mathrm{Al}$ equivalent mms., i.e $195.80 \mathrm{MGV}$ corresponds to $7.93 \mathrm{~mm}$ aluminum of the step wedge $(17,18)$. The correlations between the MGVs and Al thicknesses were described as $y=18.989 x+45.161$ for the first digital image. The same procedure was repeated for all digital images and the radiopacities of the test materials of these films were determined by using each radiograph's own formula and Excel software (Microsoft Excel 2016 MSO, New Mexico, USA). Then, all "Al equivalent thickness" values of each test materials were gathered and the mean MGV of each material was calculated. On all radiographic images, the same procedure was performed to measure the radiopacity of every root canal sealer in $\mathrm{mm}$ Al. The collected data were analyzed using one-way ANOVA and Holm-Sidak multi-comparison test $(p=0.05)$.

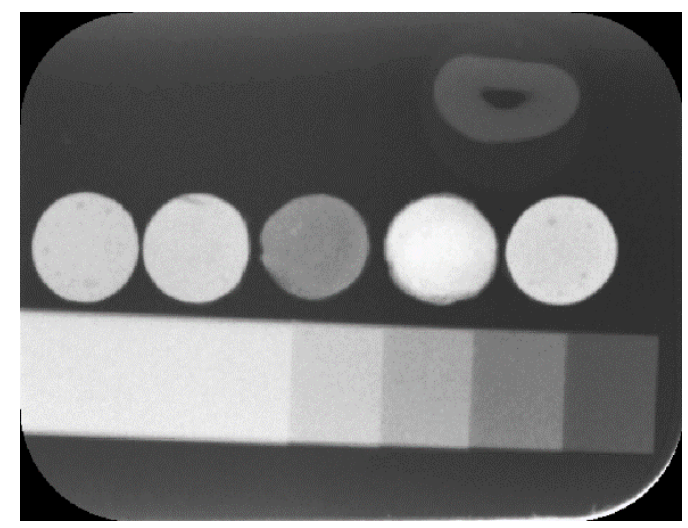

Figure 1. Standard image on the computer screen after reading of the radiography digital phosphor plate by the laser optic reader of the Digora system.

\section{SEM and EDX Analysis}

The specimens were coated with gold for electrical conductivity and examined using SEM (Thermoscientific Apreo S, Waltham, MA, USA) without any preparation or manipulation. The chemical elements of the root canal sealer specimens were analyzed using EDX (Thermoscientific Apreo $S$, Waltham, MA, USA). The metals used to sputter coat the specimens were excluded from the EDX data. EDX analyses to characterize the elemental composition were performed from the total area of each root canal sealer specimen by using EDAX Team software (EDAX., Mahwah, NJ, USA). SEM surface analysis at $x 5,000$ magnification was used to determine particle shape (globule-like and matrix) and size $(\mu \mathrm{m})$.

\section{Results}

Chemical compositions, the amount of the elements and radiopacifiers of the root canal sealer specimens according to the EDX analysis are presented in Table 1. Scanning electron micrographs at 2.500x magnification of the specimens and EDX X-ray microanalysis are presented in figure 2 . The calcium oxide-based sealer (Sealapex) showed higher calcium and bismuth peaks than the bioceramicbased sealer (MTA Fillapex), the calcium silicate-based (GuttaFlow Bioseal) and the resin-based (Adseal and Syntex) sealers. The MTA-based sealer (MTA Fillapex) contained a higher amount of tungstate then the other root canal sealers. Calcium silicate-based (GuttaFlow Bioseal) and resin-based (Adseal and Syntex) sealers showed zirconium peaks. 
Table 1 Percentage (wt \%) of elements in the tested root canal sealers according to EDX analysis

\begin{tabular}{|c|c|c|c|c|c|}
\hline \multirow{2}{*}{ Element } & \multicolumn{5}{|c|}{ Root canal sealer } \\
\hline & $\begin{array}{l}\text { Sealapex }(w t \%) \\
(\text { mean } \pm \text { SD) }\end{array}$ & $\begin{array}{l}\text { MTA Fillapex (wt } \%) \\
(\text { mean } \pm \text { SD) }\end{array}$ & $\begin{array}{l}\text { GuttaFlow Bioseal (wt\%) } \\
\quad(\text { mean } \pm \text { SD) }\end{array}$ & $\begin{array}{l}\text { Adseal }(w t \%) \\
\text { (mean } \pm \text { SD) }\end{array}$ & $\begin{array}{c}\text { Syntex }(w t \%) \\
(\text { mean } \pm \text { SD) }\end{array}$ \\
\hline CK & $35.90 \pm 1.47$ & $51.81 \pm 0.71$ & $16.98 \pm 1.34$ & $62,16 \pm 2.80$ & $60.86 \pm 2.72$ \\
\hline $0 \mathrm{~K}$ & $33.90 \pm 4.84$ & $20.26 \pm 2.66$ & $34.90 \pm 1.34$ & $17.67 \pm 1.54$ & $18,67 \pm 1.60$ \\
\hline CaK & $14.62 \pm 2.65$ & $6.57 \pm 1.31$ & $4.32 \pm 0.34$ & $5,02 \pm 0.68$ & $3.91 \pm 1.13$ \\
\hline $\mathrm{NaK}$ & trace & trace & $3.04 \pm 0.59$ & - & - \\
\hline Si K & $1.51 \pm 0,19$ & $4.20 \pm 0.52$ & $21.59 \pm 1.49$ & - & - \\
\hline S K & $2.56 \pm 0.34$ & $6.12 \pm 0.85$ & - & - & - \\
\hline${ }^{*} \mathrm{Bi} \mathrm{L}$ & $8.81 \pm 2.28$ & $0.22 \pm 0.20$ & $0.25 \pm 0.21$ & $0.08 \pm 0.05$ & $0.13 \pm 0.08$ \\
\hline Fe K & - & - & $0.70 \pm 0.13$ & $0.14 \pm 0.02$ & $0.20 \pm 0.04$ \\
\hline Zn K & $1.27 \pm 0.45$ & trace & $2.46 \pm 0.44$ & - & - \\
\hline Ti K & $1.43 \pm 0.26$ & $1,80 \pm 0.16$ & - & - & - \\
\hline${ }^{*} \mathrm{~W}$ L & - & $8.61 \pm 0.87$ & - & - & $0.28 \pm 0.06$ \\
\hline${ }^{*} \mathrm{Zr} \mathrm{K}$ & - & - & $15.65 \pm 1.93$ & $12,32 \pm 0.70$ & $13.49 \pm 2.18$ \\
\hline Tc L & trace & - & - & - & - \\
\hline PK & - & - & - & $2.64 \pm 0.12$ & $2.46 \pm 0.39$ \\
\hline $\mathrm{Mg}$ & - & - & $0.16 \pm 0.14$ & - & - \\
\hline
\end{tabular}

${ }^{*}$ Radiopacifier element
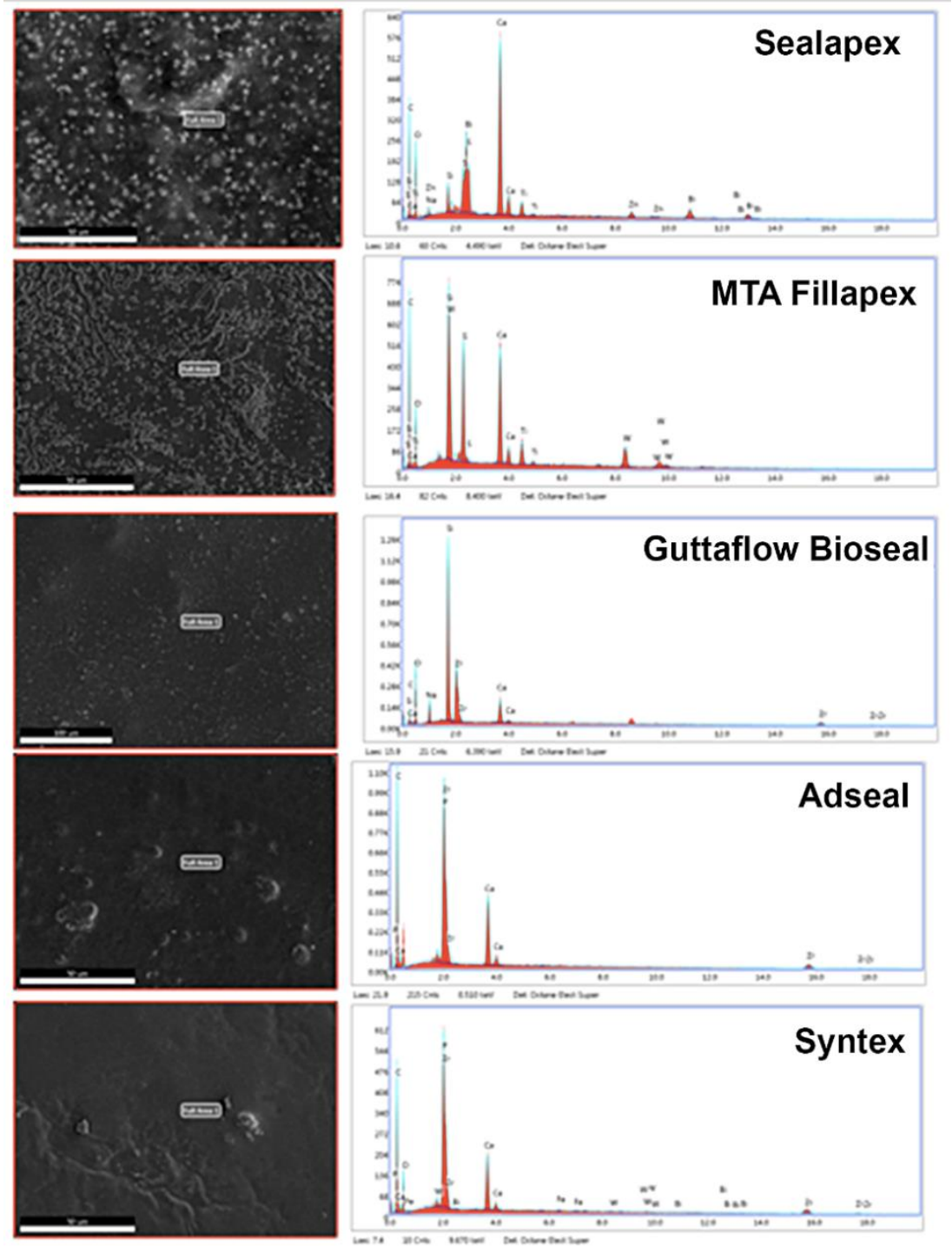

Figure 2. Scanning electron micrographs at $\times 2500$ magnification of the specimens and EDX X-ray microanalysis. 
The Sealapex specimens revealed an irregular distribution of globular-like particles in different sizes $(\approx 0.860 \mu \mathrm{m}$ to $\approx 1.210 \mu \mathrm{m})$ (Figure 3.a). MTA Fillapex specimens showed a non-uniform distribution of different sizes $(\approx 0.849 \mu \mathrm{m}$ to $\approx 2.540 \mu \mathrm{m})$ of globular-like particles that contain similar elements (Figure 3.b). On the other hand, GuttaFlow Bioseal specimens exhibited a uniform distribution of smaller sizes $(\approx 0.844 \mu \mathrm{m}$ to $\approx 1.794 \mu \mathrm{m})$ of globular-like particles that contain similar elements (Figure 3.c). Adseal and Syntex disclosed a few globular-like particles embedded in the matrices (Figs 3.d, e).
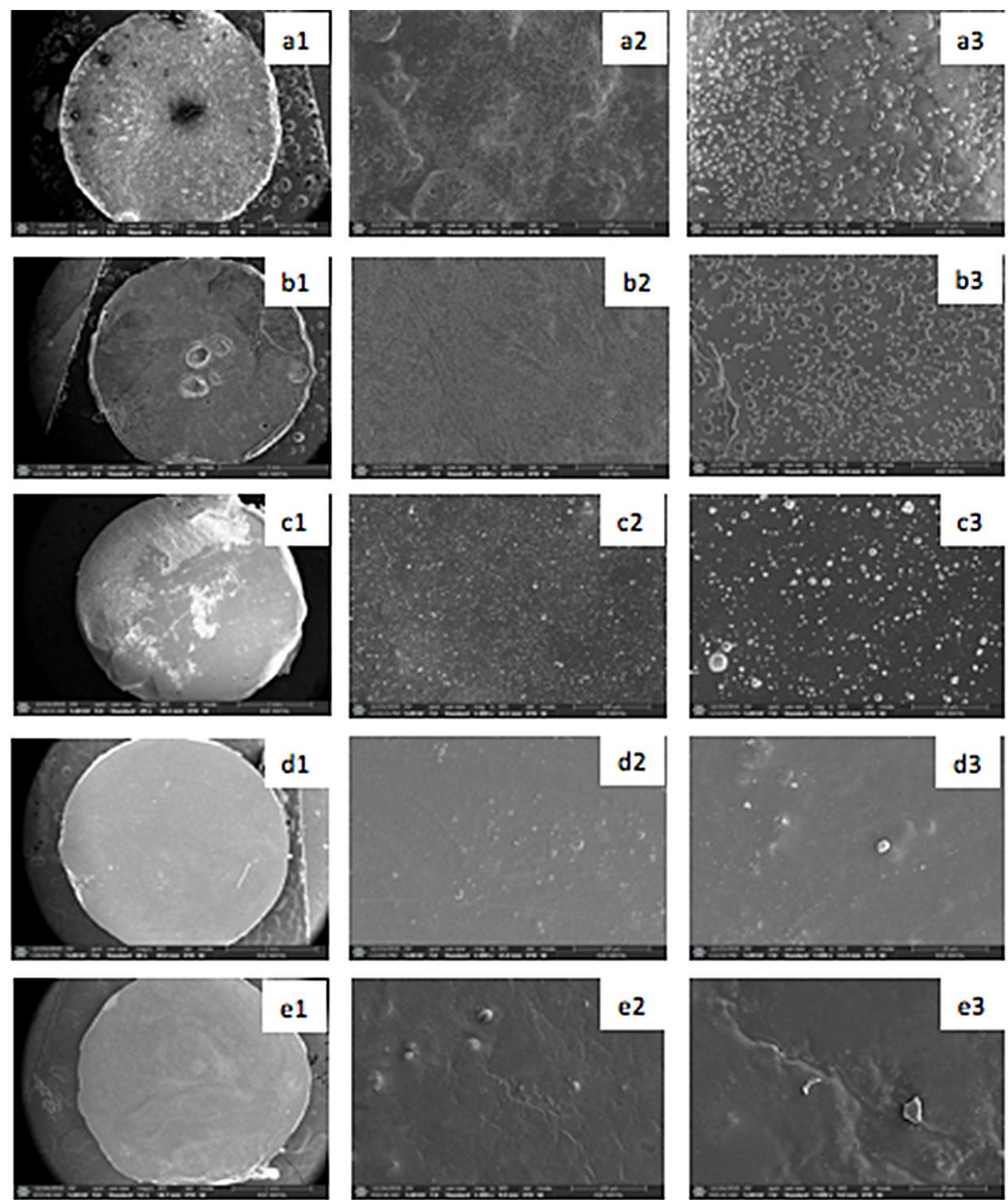

Fig. 3. Scanning electron micrographs of the specimens examined at different magnifications $(1: x 47-60,2$ : $x 1,000,3 \times 5,000)$ : Sealapex $(a 1, a 2, a 3)$, MTA Fillapex $(b 1, b 2, b 3)$, GuttaFlow Bioseal $(c 1, c 2, c 3)$, Adseal $(d 1, d 2, d 3)$ and Syntex $(\mathrm{e} 1, \mathrm{e} 2, \mathrm{e} 3)$.

The radiopacity values of the tested root canal sealers are summarized in Table 2. Sealapex presented the highest radiopacity among the tested materials $(10.01 \mathrm{~mm} \mathrm{Al}, \mathrm{p}<0.05)$. There were no significant differences between the radiopacity of Syntex ( $8.85 \mathrm{~mm} \mathrm{Al})$, GuttaFlow Bioseal $(8.87 \mathrm{~mm} \mathrm{Al})$ and Adseal $(8.39 \mathrm{~mm} \mathrm{Al})(\mathrm{p}>0.05)$. MTA Fillapex was the least radiopaque material $(4.52 \mathrm{~mm} \mathrm{Al}, \mathrm{p}<$ $0.05)$ when compared to other groups. 


\begin{tabular}{lc}
\hline Groups & $\begin{array}{c}\text { Radiopacity value (mm Al) } \\
\text { (Mean } \pm \text { SD) }\end{array}$ \\
\hline Adseal & $8.39^{\mathrm{A}} \pm 0.4$ \\
Guttaflow Bioseal & $8.87^{\mathrm{A}} \pm 0.3$ \\
MTA Fillapex & $4.52^{\mathrm{B}} \pm 0.4$ \\
Sealapex & $10.01^{\mathrm{C}} \pm 0.8$ \\
Syntex & $8.85^{\mathrm{A}} \pm 0.3$ \\
Dentin & $1.57^{\mathrm{D}} \pm 0.3$ \\
\hline
\end{tabular}

Note: Different superscript letters indicate significant difference between the materials $(p<0.05)$.

\section{Discussion}

The chemical composition of root canal sealers is the most important factor for understanding the physical, chemical and biological properties of these materials, which are in close contact with periapical tissues $(15,19,20)$. In the literature, even though there are studies regarding the radiopacity values of Adseal, GuttaFlow Bioseal, MTA Fillapex, Sealapex, there is no report about the Energydispersive X-ray Spectrometry (EDX) analysis of Adseal and Syntex. In addition, the relationship between the chemical structures and radiopacity properties of these root canal sealers has not been evaluated previously. The present study is the first report about the chemical composition of resin-based Adseal and Syntex and also first report evaluating the chemical composition effect on the radiopacity of the test materials.

Sealapex, a calcium-oxide based sealer, exhibited a high amount of calcium $(14.62 \pm 2.65 \mathrm{wt} \%)$ which confirms the manufacturer's claim that the main component of Sealapex is calcium oxide. MTA Fillapex, a bioceramic-based sealer, revealed high amounts of silicone $(4.20 \pm 0.52 \%$ wt $)$ from silicone dioxide and MTA silicates. Guttaflow Bioseal, a calcium-silicate based sealer, disclosed high amounts of silicone $(21.59 \pm 1.49 w t \%)$ from calcium silicate, and zirconium $(15.65 \pm 1.93 w t \%)$, from zirconium dioxide. The amounts of the elements as measured in this study are consistent with those of other studies, which found similar chemical compositions for MTA Fillapex and GuttaFlow Bioseal (13). Adseal, an epoxy resin based sealer, had high amounts of calcium and phosphorus from calcium phosphate, and also zirconium $(12.32 \pm 0.70 \mathrm{wt} \%)$ from zirconium dioxide. Syntex, an epoxy resin based sealer, contains high amounts of zirconium $(13.49 \pm 2.18 \mathrm{wt} \%)$, phosphorus, calcium and tungstate from calcium tungstate which were described by its manufacturer.

The present study's EDX analysis showed the presence of carbon, oxygen and calcium in the composition of all tested root canal sealers, which suggests the bioactivity and interaction of these sealers with dentin, and is also in accordance with the results from previous studies $(21,22)$. Several chemical elements such as $\mathrm{Ag}, \mathrm{Al}, \mathrm{Ba}, \mathrm{Bi}, \mathrm{Ni}, \mathrm{S}, \mathrm{Zn}, \mathrm{Zr}, \mathrm{Tc}$ and $\mathrm{W}$ may harm human cells at certain concentrations (23-25). The chemical analysis of Sealapex showed the presence of high amounts of bismuth $(8.81 \pm 2.28 w t \%)$, sulfur $(2.56 \pm 0.34 w t \%)$, zinc $(1.27 \pm 0.45 w t \%)$, and traces of technetium, and all have been associated with cytotoxicity (23-25). In Guttaflow Bioseal, high amounts of zirconium $(15.65 \pm 1.93 \mathrm{wt} \%)$, zinc, magnesium and iron were also found. Although the relative amount of magnesium is not a concern, the relatively high iron $(0.70 \pm 0.13 \mathrm{wt} \%)$ and zinc $(2.46 \pm 0.44 \mathrm{wt} \%)$ content requires screening of the toxicity of these heavy metals. The high level of zirconium $(12.32 \pm 0.70 \mathrm{wt} \%)$, and the low amounts of bismuth $(0.08 \pm 0.05 w t \%)$ and iron $(0.14 \pm 0.02 w t \%)$ in Adseal may be questioned for cytotoxic effects. Even though the cytotoxicity of Adseal due to epoxy resin components that release amine or formaldehyde during the setting reaction has been reported (26), the effect of zirconium, bismuth and iron within Adseal on toxicity cannot be assessed because of the lack of EDX analysis of this material. Similarly, the high amount of zirconium $(13.49 \pm 2.18 \mathrm{wt} \%)$ and the low amount of tungsten $(0.28 \pm 0.06 \mathrm{wt} \%)$ in Syntex may explain part of its cytotoxicity $(27,28)$.

The EDX analysis showed that Guttaflow Bioseal, Adseal and Syntex are rich in zirconium and oxygen. Zirconium oxide is an alternative radiopacifier, which has been recently manufactured and used instead of bismuth oxide in calcium silicate- and resin-based root canal sealing materials, due to its higher biocompatibility and reduced tooth discoloration $(29,30)$.

Particle size is another important feature of the root canal sealers as smaller particles may 
penetrate better into dentinal tubules and increase the adhesion to the root canal dentin (1). Small particle sizes maintain a low film thickness of the root canal sealer, which can increase the adaptation of the root canal filling material $(31,32)$. In the present study, Sealapex, MTA Fillapex and Guttaflow Bioseal had different particle sizes and all of the tested sealers had smaller particle sizes than $2 \mu \mathrm{m}$ in accordance with the literature $(21,33)$.

Radiopacity is an important property of root canal sealing materials and should allow for visualization and assessment on the radiograph (34). Minimal radiopacity of root canal sealer has to be equivalent to $3 \mathrm{~mm} \mathrm{Al}(35,36)$. In the present study, the radiopacity values were between $4.52-10.01 \mathrm{~mm}$ $\mathrm{Al}$, and all were complying with international standards. Our EDX analysis showed that each manufacturer used various compositions of different elements including zirconium oxide, bismuth oxide and calcium tungstate for achieving the required radiopacity of root canal sealers. Several studies have reported different $\mathrm{mm} \mathrm{Al}$ equivalent values for radiopacity of sealers $(37,38)$. These differences may originate either from the disparities in the Al alloy properties of the stepwedge, imaging technique, exposure parameters, and developing process $(39,40)$ or the structure, type, thickness and amount of the radiopaque agent (41).

Considering the influence of material thickness on radiopacity (ISO 6876/2012), stainless steel plates containing wells with an inner diameter of $5 \mathrm{~mm}$ and a depth of $2 \mathrm{~mm}$ were used to prepare the test samples with the same thickness of the test materials. In order to place more samples in the central part of the digital receptor (16), the inner diameter of the wells was reduced from the ANSI/ADA's specifications number 57 (36) from $10 \mathrm{~mm}$ to $5 \mathrm{~mm}$. According to Tagger and Katz (42) the advantage of decreasing the inner diameter of the wells is that the digital image can be directly measured and evaluated on the computer screen under high magnification.

It was reported that high atomic number and molecular weight increase the radiopacity value of the radiopacifier (43). The atomic numbers and molecular weights of barium, zirconium, tungstate and bismuth are $56(137,327 \mathrm{~g} / \mathrm{mol}), 40(91.224 \mathrm{~g} / \mathrm{mol}), 74(293.82 \mathrm{~g} / \mathrm{mol})$ and $84(208.98 \mathrm{~g} / \mathrm{mol})$, respectively. Additionally, the presence, quantity, and proportion of radiopacifying agents in each material would be effective on the each material's radiopacity value (44).

In this study, the highest radiopacity values were observed for Sealapex, which had bismuth as a radiopacifier in its new composition instead of barium in a former formulation (45). The higher atomic number and molecular weight of bismuth than barium may be accountable for the increased radiopacity value (46), because the highest amount of bismuth $(8.81 \pm 2.28 \mathrm{wt} \%)$ was observed in Sealapex with our EDX analysis. The radiopacity value of Sealapex is in accordance with those obtained by Bodrumlu et al. (37) and Tonamaru-Filho et al. (47).

Adseal, Syntex and GuttaFlow Bioseal revealed similar radiopacity values. The radiopacity of GuttaFlow Bioseal may be associated with the presence of zirconium dioxide and nano silver particles $(48,49)$. On the other hand, those of Adseal and Syntex may be related to the iron oxide, zirconium oxide, and calcium tungstate in their formulations since the level of zirconium in GuttaFlow Bioseal was $15.65 \pm 1.93 \mathrm{wt} \%$, Syntex was $13.49 \pm 2.18 \mathrm{wt} \%$, and Adseal $12.32 \pm 0.70 \mathrm{wt} \%$ in the EDX analysis, and these results were in accordance with their radiopacity values. The results of this study are consistent with others, which found similar radiopacity values for Adseal (14) and GuttaFlow Bioseal $(48,49)$, however, there was no report in the literature about the radiopacity value of Syntex.

In the present study, MTA Fillapex contained two chemical components responsible for its radiopacity, tungstate $(8.61 \pm 0.87 \mathrm{wt} \%)$ and bismuth $(0.22 \pm 0.20 \mathrm{wt} \%)$. A reason for the low value for MTA Fillapex may be related to lower radiopacifying potential of tungstate (50). Even though the atomic number of tungstate is higher than zirconium, the wt $\%$ of this material is lower in MTA Fillapex and this may be considered as the cause of lower radiopacity in this study sample (44). MTA Fillapex presented the lowest radiopacity and this result is similar to that reported by Tonamaru-Filho et al. (47) and Vidotto et al. (51).

Clinicians should be aware of the radiopacity of the root canal sealer they use. In the endodontic treatment, the materials should ideally be sufficiently radiopaque in order to determine the filling's quality $(2,52)$ and distinguishing the material from the surrounding anatomic structures $(4,53)$. Additionally, in the retreatment cases the location of the margins of a root canal filling is of great importance, since the radiographical detection of an unsuccessful root canal treatment. A sealer with low radiopacity may not be clearly detected on the radiograph and removal of the sealer from the root canal walls may be inadequate, thus, infected remnants of the material would eventually cause unsuccessful retreatment outcomes. Therefore, using the sealers with the highest radiopacity value may help clinicians in cases with recurrent periapical lesions in order to diminish the above mentioned disadvantages. 


\section{Conclusions}

Within the limitations of this study, EDX analysis showed that each root canal sealer contains different compositions of radiopacifiers including bismuth oxide, calcium tungstate and zirconium oxide. All the tested root canal sealers had radiopacity values above the ISO-specified limit. Sealapex was the most radiopaque root canal sealer followed by GuttaFlow Bioseal, Syntex and Adseal, whereas MTA Fillapex was the least radiopaque root canal sealer. Additionally, no association was observed between the particle size and the radiopacity.

\section{Acknowledgements}

The authors would like to thank Assoc. Prof. Dr.Timur Köse from Ege University, Faculty of Medicine, Department of Biostatistics and Medical Informatics, for his valuable contributions in statistical analyses and interpretations of data.

\section{Disclosure Statement}

The authors declare that they have no conflict of interest.

\section{Funding}

There is no funding.

\section{Resumo}

Os cimentos endodônticos devem conter ótima adesão à dentina radicular, baixa citotoxicidade, radiopacidade suficiente e estabilidade dimensional elevada, que dependem principalmente da sua composição química. Os objetivos deste estudo foram avaliar a composição química de Syntex (Cerkamed, Stalowa Wola, Polônia), Adseal (Meta Biomed, Cheongju-si, Coreia), Sealapex (SybronEndo, Scafati, Itália), MTA Fillapex (Angelus, Londrina, Brasil) e GuttaFlow Bioseal (Coltene/Whaledent, Altstätten, Suiça) e determinar comparativamente a sua radiopacidade. Foram construídos moldes de aço inoxidável com um diâmetro interior de $5 \mathrm{~mm}$ e uma profundidade de 2 $\mathrm{mm}$. Os cimentos testados foram misturados e vertidos em moldes. Após a fixação, foram feitas radiografias periapicais digitais dos espécimes $(n=12)$ em condições de exposição padrão e os valores médios de cinza dos espécimes foram medidos utilizando um programa de computação gráfica. Em seguida, as amostras foram examinadas por microscopia eletrônica de varredura, e foi realizada uma análise de raios $X$ dispersiva de energia. Os dados foram analisados utilizando a ANOVA unidirecional seguida do teste de comparação múltipla Holm-Sidak $(p=0,05)$. 0 Sealapex mostrou um pico de cálcio mais elevado do que os cimentos MTA Fillapex, GuttaFlow Bioseal, Adseal e Syntex. O MTA Fillapex continha uma quantidade mais elevada de tungstato. 0 Sealapex apresentou o maior valor de radiopacidade entre os materiais testados $(p<0,05)$, enquanto que a MTA Fillapex foi o material menos radiopaco $(p<0,05)$. Cada cimento endodôntico contém diferentes composições de radiopacificadores incluindo óxido de bismuto, tungstato de cálcio e óxido de zircônio. Os cimentos testados apresentaram valores de radiopacidade acima do limite especificado pela ISO. Sealapex foi o cimento obturador mais radiopaco seguido por GuttaFlow Bioseal, Syntex, Adseal e MTA Fillapex. 


\section{References}

1. Ørstavik D. Materials used for root canal obturation; technique, biological and clinical testing. Endod Top. 2005; 12: 25-38.

2. Ørstavik D, Eriksen HM, Beyer-Olsen EM. Adhesive properties and leakage of root canal sealers in vitro. Int Endod J 1983; 16: 59-63.

3. Zhou HM, Shen Y, Zheng W, Li L, Zheng YF, Haapasalo M. Physical properties of 5 root canal sealers. J Endod 2013; 39: 1281-1286.

4. Zordan-Bronzel CL, Esteves Torres FF, Tanomaru-Filho M, Chávez-Andrade GM, Bosso-Martelo R, Guerreiro-Tanomaru JM. Evaluation of physicochemical properties of a new calcium silicate-based sealer, bio-c Sealer. J Endod 2019; 45: 1248-1252.

5. Candeiro GTM, Lavor AB, Lima ITF, Vasconcelos BC, Gomes NV, Iglecias EF, Gavini G. Penetration of bioceramic and epoxy-resin endodontic cements into lateral canals. Braz Oral Res 2019; 27: e049.

6. Leonardo MR, da Silva LA, Utrilla LS, Assed S, Ether SS. Calcium hydroxide root canal sealers histopathologic evaluation of apical and periapical repair after endodontic treatment. J Endod 1997; 23: 428-432.

7. Tanomaru JMG, Cezare L, Gonçalves M, Tanomaru-Filho M. Evaluation of the radiopacity of root canal sealers by digitalization of radiographic images. J Appl Oral Sci 2004; 12: 355-357.

8. Bier C, Rosa RA, So MVR, Tonamaru JMG, Tonamaru Filho M. Push-out bond strength of Calcium hydroxide and Mineral trioxide aggregate based sealers to root canal dentin. Rev Odonto Cienc 2012; 27: $320-324$.

9. Torabinejad M, Chivian N. Clinical applications of mineral trioxide aggregate. J Endod 1999; 25: 197-205.

10. Duarte MAH, Marciano MA, Vivan RR, Tanomaru Filho M, Tanomaru JMG, Camilleri J. Tricalcium silicate-based cements: properties and modifications. Braz Oral Res 2018; 18: e70.

11. Camilleri J. Sealers and warm gutta-percha obturation techniques. J Endod 2015;41:72-78.

12. Gandolfi MG, Siboni F, Prati C. Properties of a novel polysiloxane-gutta percha calcium silicatebioglass-containing root canal sealer. Dent Mater 2016; 32, e113-26.

13. Collado-González M, Tomás-Catalá CJ, Oñate-Sánchez RE, Moraleda JM, Rodríguez-Lozano FJ. Cytotoxicity of GuttaFlow Bioseal, GuttaFlow2, MTA Fillapex, and AH Plus on human periodontal ligament stem cells. J Endod 2017; 43: 816-822.

14. Song YS, Choi Y, Lim MJ, Yu MK, Hong CU, Lee KW, Min KS. In vitro evaluation of a newly produced resin-based endodontic sealer. Restorative Dent Endod 2016; 41: 189-195.

15. Sari, S; Duruturk, L. Radiographic evaluation of periapical healing of permanent teeth with periapical lesions after extrusion of AH Plus sealer. Oral Surg Oral Med Oral Pathol Oral Radiol Oral Endod 2007; 104: 54-59.

16. Carvalho-Junior JR, Correr-Sobrinho L, Correr AB, Sinhoreti MA, Consani S, Sousa-Neto MD. Radiopacity of root filling materials using digital radiography. Int Endod J 2007; 40: 514-520.

17.Ergücü Z, Türkün LS, Önem E, Güneri P. Comparative radiopacity of six flowable resin composites. Oper Dent 2010; 35: 436-440

18. Erzurumlu ZU, Sagirkaya CE, Erzurumlu K. Evaluation of radiopacities of CAD/CAM restorative materials and resin cements by digital radiography. Clin Oral Invest 2021; Mar 11.

19. Teixeira L, Basso FG, Hebling J, Costa CAS, Mori GG, Silva-Sousa YTC, Oliveira CF. Cytotoxicity evaluation of root canal sealers using an in vitro experimental model with roots. Braz Dent J 2017; 28: 165-171.

20. Oh H, Kim E, Lee S, Park S, Chen D, Shin SJ, Kim E, Kim S. Comparison of biocompatibility of calcium silicate-based sealers and epoxy resin-based sealer on human periodontal ligament stem cells. Materials 2020; 20: 5242.

21. Reszka P, Nowicka A, Lipski M, Dura W, Droździk A, Woźniak K. A comparative chemical study of calcium silicate-containing and epoxy resin-based root canal sealers. BioMed Res Inter 2016;2016: 9808432.

22. Erik $A A$, Erik CE, Yıldırım D. Experimental study of influence of composition on radiopacity of fiber post materials. Micros Res Tech 2019; 82: 1448-1454.

23. Figueiredo JA, Pesce HF, Gioso MA, Figueiredo MA. The histological effects of four endodontic sealers implanted in the oral mucosa: submucous injection versus implant in polyethylene tubes. Int Endod J 2001; 34: 377-385.

24. Scelza MZ, Linhares $A B$, da Silva LE, Granjeiro JM, Alves GG. A multiparametric assay to compare the cytotoxicity of endodontic sealers with primary human osteoblasts. Int Endod J 2012; 45: 12-18. 
25. Silva EJ, Accorsi-Mendonça T, Almeida JF, Ferraz CC, Gomes BP, Zaia AA. Evaluation of cytotoxicity and up-regulation of gelatinases in human fibroblast cells by four root canal sealers. Int Endod J 2012; 45: 49-56.

26. Cohen $\mathrm{BI}$, Pagnillo MK, Musikant BL, Deutsch AS. An in vitro study of the cytotoxicity of two root canal sealers. J Endod 2000; 26: 228-229.

27. Chen $C_{1}$ Hsieh SC, Teng NC, Kao CK, Lee SY, Lin CK, et al. Radiopacity and cytotoxicity of Portland cement containing zirconia doped bismuth oxide radiopacifiers. J Endod 2014; 40: 251-254.

28. Karthiga P, Ponnanikajamideen $M$, Samuel Rajendran $R$, Annadurai G, Rajeshkumar $S$. Characterization and toxicology evaluation of zirconium oxide nanoparticles on the embryonic development of zebrafish, Danio rerio. Drug Chem Toxicol 2019; 42: 104-111.

29. Marciano MA, Duarte $H_{1}$ Camilleri J. Dental discoloration caused by bismuth oxide in MTA in the presence of sodium hypochlorite. Clin Oral Invest 2015; 19: 2201-2209.

30. Walsh RM, He J, Schweitzer J, Opperman LA, Woodmansey KF. Bioactive endodontic materials for everyday use: a review. Gen Dent 2018; 66: 48-51.

31. Komabayashi T, Spångberg LS. Comparative analysis of the particle size and shape of commercially available mineral trioxide aggregates and Portland cement: a study with a flow particle image analyzer. J Endod 2008; 34: 94-98.

32. Torabinejad M, Parirokh $M$, Dummer PMH. Mineral trioxide aggregate and other bioactive endodontic cements: an updated overview - part II: other clinical applications and complications. Int Endod J 2018; 51: 284-317.

33. Hoikkala NJ, Wang X, Hupa L, Smått JH, Peltonen J, Vallittu PK. Dissolution and mineralization characterization of bioactive glass ceramic containing endodontic sealer Guttaflow Bioseal. Dent Mater J 2018; 37: 988-994.

34. Baksi BG, Sen BH, Eyuboglu TF. Differences in aluminum equivalent values of endodontic sealers: conventional versus digital radiography. J Endod 2008; 34: 1101-1104.

35. International Organization for Standardization (ISO) 6876. Dental root canal sealing materials. Geneva, Switzerland, 2012.

36. American National Standards Institute/American Dental Association (ANSI/ADA) Specification No. 57, Endodontic sealing materials. New York, 2000.

37. Bodrumlu E, Sumer P, Gungor K. Radiopacity of a new root canal sealer, epiphany. Oral Surg Oral Med Oral Pathol Oral Radiol Endod 2007; 104: e59-e61.

38. Tanomaru-Filho $M$, Torres FFE, Chaves-Andrade GM, Almeida $M$, Navarro LG, Steier $L$, et al. Physicochemical properties and volumetric change of Silicone/Bioactive Glass and Calcium Silicate-based endodontic sealers. J Endod 2017; 43: 2097-2101.

39. el-Mowafy OM, Benmergui C. Radiopacity of resin-based inlay luting cements. Oper Dent 1994; 19: 11-15.

40. Laghios CD, Benson BW, Gutmann JL, Cutler CW. Comparative radiopacity of tetracalcium phosphate and other root-end filling materials. Int Endod J 2000; 33: 311-315.

41. Karagöz I, Küçükay S, Bayırlı G. Factors affecting apical leakage assessment. J Endod 1993; 19: 362-365.

42. Tagger $M$, Katz A. Radiopacity of endodontic sealers: development of a new method for direct measurement. J Endod 2003; 29: 751-755.

43. Martinez Rus F, Garcia AM, de Aza AH, Pradies G. Radiopacity of zirconia-based all-ceramic crown systems. Int J Prosthodont 2011; 24: 144-146.

44. Candeiro GT, Correia FC, Duarte MA, et al. Evaluation of radiopacity, $\mathrm{pH}$, release of calcium ions, and flow of a bioceramic root canal sealer. J Endod 2012; 38: 842-5.

45. Guerreiro-Tanomaru JM, Duarte MA, Gonçalves M, Tanomaru-Filho M. Radiopacity evaluation of root canal sealers containing calcium hydroxide and MTA. Braz Oral Res 2009; 23: 119-123.

46. Tsuge T. Radiopacity of conventional, resin-modified glass ionomer, and resin-based luting materials. J Oral Sci 2009;51: 223-230

47. Tanomaru-Filho $M$, Cristine Prado $M$, Torres FFE, Viapiana $R$, Pivoto-João MMB, GuerreiroTanomaru JM. Physicochemical properties and bioactive potential of a new epoxy resin-based root canal sealer. Braz Dent J 2019; 30: 563-568.

48. Camargo RV, Silva-Sousa YTC, Rosa RPFD, Mazzi-Chaves JF, Lopes FC, et al. Evaluation of the physicochemical properties of silicone- and epoxy resin-based root canal sealers. Braz Oral Res 2017; 21(e72).

49. Flores DS, Rached FJ, Versiani MA, Guedes DF, Sousa-Neto MD, Pécora JD. Evaluation of physicochemical properties of four root canal sealers. Int Endod J 2011; 44: 126-135. 
50. Hungaro Duarte MA, de Oliveira El Kadre GD, Vivan RR, Guerreiro Tanomaru JM, Tanomaru Filho $M$, de Moraes IG. Radiopacity of Portland cement associated with different radiopacifying agents. J Endod 2009; 35: 737-740.

51. Vidotto APM, Cunha RS, Zaferino EG, Rocha DGP, Martin AS, Bueno CE. Comparison of MTA Fillapex radiopacity with five root canal sealers. RSBO 2011; 8: 404-409.

52. Versiani MA, Abi Rached-Junior FJ, Kishen $A$, et al. Zinc oxide nanoparticles enhance physicochemical characteristics of Grossman sealer. J Endod 2016;42:1804-10.

53. Vivan RR, Ordinola-Zapata R, Bramante $C M$, et al. Evaluation of the radiopacity of some commercial and experimental root-end filling materials. Oral Surg Oral Med Oral Pathol Oral Radiol Endod 2009;108:e35-8.

Received: 06/08/2021

Accepted: 29/09/2021 